\title{
Synthesis, Characterization and Crystal Structures of Schiff Base Copper Complexes with Urease Inhibitory Activity
}

\author{
Shuang Han ${ }^{1}$ and Yuan Wang ${ }^{2, *}$ \\ ${ }^{1}$ College of Chemistry and Chemical Engineering, Qiqihar University, Qiqihar 161006, P.R. China \\ ${ }^{2}$ Heilongjiang Province Qiqihar Ecological Environment Monitoring Center, Qiqihar 161005, P.R. China \\ *Corresponding author: E-mail: qqhrwangyuan@163.com
}

Received: 05-24-2021

\begin{abstract}
Urease inhibitors can inhibit the decomposition rate of urea, and decrease the air pollution caused by ammonia. In this paper, four new copper(II) complexes $\left[\mathrm{CuL}\left(\mathrm{ONO}_{2}\right)\right]_{\mathrm{n}}(\mathbf{1}),\left[\mathrm{Cu}_{2} \mathrm{~L}_{2}\left(\mu_{1,3}-\mathrm{N}_{3}\right)_{2}\right](\mathbf{2}),[\mathrm{CuBrL}](\mathbf{3})$, and $[\mathrm{CuClL}](\mathbf{4})$, where $\mathrm{L}=$ 5-bromo-2-(((2-methylamino)ethyl)imino)methyl)phenolate, have been synthesized and characterized. The complexes were characterized by elemental analyses, IR and UV-Vis spectroscopy, molar conductivity, and single crystal X-ray diffraction. X-ray analysis reveals that $\mathrm{Cu}$ atoms in complexes $\mathbf{1}$ and $\mathbf{2}$ are in square pyramidal coordination, and those in complexes $\mathbf{3}$ and $\mathbf{4}$ are in square planar coordination. The molecules of the complexes are linked through hydrogen bonds and $\pi \cdots \pi$ interactions. The inhibitory effects of the complexes on Jack bean urease were studied, which showed that the complexes have effective activity on urease.
\end{abstract}

Keywords: Schiff base; Copper complex; X-ray diffraction; Urease inhibitory activity

\section{Introduction}

Urea is a major nitrogen-containing soil fertilizer, with an annual production projected to reach 226 million tons in $2021 .{ }^{1}$ Once deposited in soil, urea quickly hydrolyzes by urease to yield $\mathrm{NH}_{3} .{ }^{2}$ This reaction causes a number of agronomic, environmental and economic problems and affects the global nitrogen cycle. ${ }^{3}$ In particular, too rapid increase of soil $\mathrm{pH}$ upon urea hydrolysis catalyzed by urease activity causes the loss of urea nitrogen as gaseous ammonia, which is toxic to plants and contributes to the production of fine inorganic particulate matter. ${ }^{4}$ This process causes tropospheric pollution by $\mathrm{NO}, \mathrm{NO}_{2}$ and $\mathrm{N}_{2} \mathrm{O}$, which is a greenhouse gas with 300 times the heat trapping capacity of $\mathrm{CO}_{2} \cdot{ }^{5}$ Urease occurs widely in most bacteria, plants, algae, fungi and invertebrates. ${ }^{6}$ Urease enzyme catalyzes the decomposition of urea into ammonia in high efficiency, with the rate $10^{14}$ times faster than the non-catalyzed reaction. ${ }^{7}$ This process is harmful for the health of human beings and environment. The use of inhibitors proves to be a good way to solve this problem. ${ }^{8}$ Recent research indicated that metal complexes have interesting activities on urease. ${ }^{9}$ However, the study on this topic is limited, and no definite relationship between structures and properties is given. Schiff bases are a kind of interesting ligands in the formation of metal complexes, which have received particular attention due to their facile synthesis, versatile structures, and good biological activities. ${ }^{10}$ Schiff base complexes of copper, cobalt, nickel and zinc are reported to have urease inhibitory activities. ${ }^{11}$ In pursuit of exploring novel urease inhibitors, four new copper complexes $\left[\mathrm{CuL}\left(\mathrm{ONO}_{2}\right)\right]_{\mathrm{n}}(\mathbf{1}), \quad\left[\mathrm{Cu}_{2} \mathrm{~L}_{2}\right.$ $\left.\left(\mu_{1,3}-\mathrm{N}_{3}\right)_{2}\right](2),[\mathrm{CuBrL}](3)$, and [CuClL] (4), where $\mathrm{L}=$ 5-bromo-2-(((2-methylamino)ethyl)imino)methyl)phenolate, are presented.

\section{Experimental}

\section{1. General Methods and Materials}

4-Bromosalicylaldehyde and $\mathrm{N}$-methylethane -1,2-diamine were purchased Lancaster and used as received. All other reagents were of analytical reagent grade. Elemental analyses of $\mathrm{C}, \mathrm{H}$ and $\mathrm{N}$ were carried out in a 2400 Series-II CHN analyzer. FT-IR spectra were obtained on a Jasco FT/IR-4000 spectrometer with samples pre- 
pared as $\mathrm{KBr}$ pellets. Electronic spectra were obtained with Lambda 35 spectrophotometer. Single crystal X-ray diffraction was carried out with a Bruker Apex II CCD diffractometer. Molar conductance was measured with a Shanghai DDS-11A conductometer.

Caution! Although our samples never exploded during handling, azide compounds are potentially explosive. Only a small amount of azide compound should be prepared and it should be handled with care.

\section{2. Synthesis of Complex 1}

4-Bromosalicylaldehyde $(0.20 \mathrm{~g}, 1.0 \mathrm{mmol})$ and $\mathrm{N}$-methylethane-1,2-diamine $(0.074 \mathrm{~g}, 1.0 \mathrm{mmol})$ were dissolved and mixed in methanol $(30 \mathrm{~mL})$. The mixture was stirred at room temperature for $10 \mathrm{~min}$ to give a yellow solution. To the solution was added dropwise a methanol solution $(20 \mathrm{~mL})$ containing copper nitrate $(0.24 \mathrm{~g}, 1.0$ $\mathrm{mmol}$ ). The color changed to blue immediately. The mixture was further stirred at room temperature for $30 \mathrm{~min}$ and filtered. The filtrate was kept at ambient temperature. Single crystals of the complex, suitable for X-ray diffraction, were grown from the filtrate upon slow evaporation within a few days. The crystals were isolated by filtration, washed with methanol and dried in air. Yield: 0.23 g (61\%). Anal. Calcd. for $\mathrm{C}_{10} \mathrm{H}_{12} \mathrm{BrCuN}_{3} \mathrm{O}_{4}$ (\%): C, 31.47; H, 3.17; N, 11.01. Found (\%): C, 31.28; H, 3.26; N, 11.23 . IR data $\left(\mathrm{KBr}, \mathrm{cm}^{-1}\right): 3151(\mathrm{NH}), 1647(\mathrm{C}=\mathrm{N}), 1421,1272$, $1086\left(\mathrm{NO}_{3}\right)$. UV-Vis data in methanol $\left[\lambda_{\max }(\mathrm{nm})\right]: 230$, $245,271,363$.

\section{3. Synthesis of Complex 2}

4-Bromosalicylaldehyde $(0.20 \mathrm{~g}, 1.0 \mathrm{mmol})$ and $\mathrm{N}$-methylethane-1,2-diamine $(0.074 \mathrm{~g}, 1.0 \mathrm{mmol})$ were dissolved and mixed in methanol $(30 \mathrm{~mL})$. The mixture was stirred at room temperature for $10 \mathrm{~min}$ to give a yellow solution. To the solution was added dropwise a methanol solution $(20 \mathrm{~mL})$ containing copper bromide $(0.22$ $\mathrm{g}, 1.0 \mathrm{mmol})$ and sodium azide $(0.065 \mathrm{~g}, 1.0 \mathrm{mmol})$. The color changed to blue immediately. The mixture was further stirred at room temperature for $30 \mathrm{~min}$ and filtered. The filtrate was kept at ambient temperature. Single crystals of the complex, suitable for X-ray diffraction, were grown from the filtrate upon slow evaporation within a few days. The crystals were isolated by filtration, washed with methanol and dried in air. Yield: $0.13 \mathrm{~g}(36 \%)$. Anal. Calcd. for $\mathrm{C}_{20} \mathrm{H}_{24} \mathrm{Br}_{2} \mathrm{Cu}_{2} \mathrm{~N}_{10} \mathrm{O}_{2}$ (\%): C, 33.21; $\mathrm{H}, 3.34 ; \mathrm{N}$, 19.36. Found (\%): C, 33.37; H, 3.45; N, 19.20. IR data $(\mathrm{KBr}$, $\left.\mathrm{cm}^{-1}\right): 3172(\mathrm{NH}), 1645(\mathrm{C}=\mathrm{N}), 2078\left(\mathrm{~N}_{3}\right)$. UV-Vis data in methanol $\left[\lambda_{\max }(\mathrm{nm})\right]: 230,248,272,361$.

\section{4. Synthesis of Complex 3}

4-Bromosalicylaldehyde $(0.20 \mathrm{~g}, 1.0 \mathrm{mmol})$ and $\mathrm{N}$-methylethane-1,2-diamine $(0.074 \mathrm{~g}, 1.0 \mathrm{mmol})$ were dissolved and mixed in methanol $(30 \mathrm{~mL})$. The mixture was stirred at room temperature for $10 \mathrm{~min}$ to give a yellow solution. To the solution was added dropwise a methanol solution $(20 \mathrm{~mL})$ containing copper bromide $(0.22 \mathrm{~g}$, $1.0 \mathrm{mmol}$ ). The color changed to deep blue immediately. The mixture was further stirred at room temperature for $30 \mathrm{~min}$ and filtered. The filtrate was kept at ambient temperature. Single crystals of the complex, suitable for X-ray diffraction, were grown from the filtrate upon slow evaporation within a few days. The crystals were isolated by filtration, washed with methanol and dried in air. Yield: 0.26 g (65\%). Anal. Calcd. for $\mathrm{C}_{10} \mathrm{H}_{12} \mathrm{Br}_{2} \mathrm{CuN}_{2} \mathrm{O}$ (\%): C, 30.06; H, 3.03; N, 7.01. Found (\%): C, 29.87; H, 3.12; N, 6.93. IR data $\left(\mathrm{KBr}, \mathrm{cm}^{-1}\right): 3201(\mathrm{NH}), 1640(\mathrm{C}=\mathrm{N})$. UV-Vis data in methanol $\left[\lambda_{\max }(\mathrm{nm})\right]: 230,245,280,365$.

\subsection{Synthesis of Complex 4}

4-Bromosalicylaldehyde $(0.20 \mathrm{~g}, 1.0 \mathrm{mmol})$ and $\mathrm{N}$-methylethane-1,2-diamine $(0.074 \mathrm{~g}, 1.0 \mathrm{mmol})$ were dissolved and mixed in methanol $(30 \mathrm{~mL})$. The mixture was stirred at room temperature for $10 \mathrm{~min}$ to give a yellow solution. To the solution was added dropwise a methanol solution $(20 \mathrm{~mL})$ containing copper chloride $(0.13 \mathrm{~g}$, $1.0 \mathrm{mmol}$ ). The color changed to deep blue immediately. The mixture was further stirred at room temperature for $30 \mathrm{~min}$ and filtered. The filtrate was kept at ambient temperature. Single crystals of the complex, suitable for X-ray diffraction, were grown from the filtrate upon slow evaporation within a few days. The crystals were isolated by filtration, washed with methanol and dried in air. Yield: 0.21 $\mathrm{g}(58 \%)$. Anal. Calcd. for $\mathrm{C}_{10} \mathrm{H}_{12} \mathrm{BrClCuN}_{2} \mathrm{O}$ (\%): C, 33.82; $\mathrm{H}, 3.41 ; \mathrm{N}, 7.89$. Found (\%): C, 33.95; H, 3.30; N, 7.81. IR data $\left(\mathrm{KBr}, \mathrm{cm}^{-1}\right): 3198(\mathrm{NH}), 1640(\mathrm{C}=\mathrm{N})$. UV-Vis data in methanol $\left[\lambda_{\max }(\mathrm{nm})\right]: 230,247,278,367$.

\section{6. X-Ray Structure Determination}

Single-crystal X-ray diffraction data for the complexes were collected on a Bruker Apex II CCD diffractometer at 298(2) K with Mo $K_{\alpha}$ radiation $(\lambda=0.71073$ $\AA$ ) by $\omega$ scan mode. The program SAINT was used for integration of the diffraction profiles. ${ }^{12}$ The structures were solved by direct methods using the SHELXS program of the SHELXTL package and refined by full-matrix leastsquares methods with SHELXL (semi-empirical absorption corrections were applied using the SADABS program). ${ }^{13}$ The positions of the non-hydrogen atoms were located in difference Fourier syntheses and least-squares refinement cycles, and finally refined anisotropically. All hydrogen atoms of the complexes were placed theoretically onto the specific atoms and refined isotropically as riding atoms. Crystallographic data and experimental details for structural analyses are summarized in Table 1. Selected bond lengths and angles for the complex are listed in Table 2. 
Table 1. Crystallographic data and refinement details for the complexes.

\begin{tabular}{|c|c|c|c|c|}
\hline & 1 & 2 & 3 & 4 \\
\hline Formula & $\mathrm{C}_{10} \mathrm{H}_{12} \mathrm{BrCuN}_{3} \mathrm{O}_{4}$ & $\mathrm{C}_{20} \mathrm{H}_{24} \mathrm{Br}_{2} \mathrm{Cu}_{2} \mathrm{~N}_{10} \mathrm{O}_{2}$ & $\mathrm{C}_{10} \mathrm{H}_{12} \mathrm{Br}_{2} \mathrm{CuN}_{2} \mathrm{O}$ & $\mathrm{C}_{10} \mathrm{H}_{12} \mathrm{BrClCuN}_{2} \mathrm{O}$ \\
\hline Formula weight & 381.68 & 723.39 & 399.58 & 355.12 \\
\hline Crystal color, shape & Blue, block & Blue, block & Blue, block & Blue, block \\
\hline Crystal system & Monoclinic & Orthorhombic & Orthorhombic & Orthorhombic \\
\hline Space group & $P 2_{1}$ & $\mathrm{Pbcn}$ & $\mathrm{Pbca}$ & $\mathrm{Pbca}$ \\
\hline$a(\AA)$ & $7.6706(10)$ & $16.8624(12)$ & $17.1761(11)$ & $17.012(9)$ \\
\hline$b(\AA)$ & $8.1444(12)$ & $7.1989(11)$ & $6.8686(12)$ & $6.930(4)$ \\
\hline$c(\AA)$ & $10.712(2)$ & $21.0019(13)$ & $21.3893(12)$ & $21.828(11)$ \\
\hline$\beta\left({ }^{\circ}\right)$ & $94.035(2)$ & 90 & 90 & 90 \\
\hline$V\left(\AA^{3}\right)$ & $667.58(19)$ & $2549.4(5)$ & $2523.4(5)$ & $2574(2)$ \\
\hline$Z$ & 2 & 4 & 8 & 8 \\
\hline$D_{\text {calcd }}\left(\mathrm{g} \mathrm{cm}^{-3}\right)$ & 1.899 & 1.885 & 2.104 & 1.833 \\
\hline$\mu\left(\mathrm{Mo} \mathrm{K} \alpha, \mathrm{mm}^{-1}\right)$ & 4.641 & 4.843 & 8.044 & 4.990 \\
\hline Reflections collected & 3909 & 12296 & 12465 & 12598 \\
\hline Unique & 2304 & 2374 & 2348 & 2407 \\
\hline Observed reflections $(I \geq 2 \mathrm{~s}(I))$ & 2116 & 1714 & 1818 & 1931 \\
\hline Data/restraints/parameters & $2304 / 1 / 173$ & $2374 / 0 / 164$ & $2348 / 0 / 146$ & $2407 / 0 / 146$ \\
\hline Goodness of fit on $F^{2}$ & 1.032 & 1.078 & 1.073 & 1.103 \\
\hline$R_{1}, w R_{2}(I \geq 2 \mathrm{~s}(I))^{a}$ & $0.0276,0.0713$ & $0.0435,0.0888$ & $0.0388,0.0921$ & $0.0431,0.1029$ \\
\hline$R_{1}, w R_{2}(\text { all data })^{a}$ & $0.0310,0.0728$ & $0.0710,0.0985$ & $0.0560,0.0995$ & $0.0563,0.1091$ \\
\hline
\end{tabular}

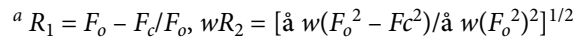

Table 2. Selected bond distances $(\AA)$ and angles $\left(^{\circ}\right)$ for the complexes.

\begin{tabular}{|c|c|c|c|}
\hline \multicolumn{4}{|c|}{1} \\
\hline $\mathrm{Cu} 1-\mathrm{O} 1$ & $1.913(4)$ & $\mathrm{Cu} 1-\mathrm{O} 2$ & $2.045(4)$ \\
\hline $\mathrm{Cu} 1-\mathrm{N} 1$ & $1.929(5)$ & $\mathrm{Cu} 1-\mathrm{N} 2$ & $2.029(5)$ \\
\hline $\mathrm{O} 1-\mathrm{Cu} 1-\mathrm{N} 1$ & $94.69(19)$ & $\mathrm{O} 1-\mathrm{Cu} 1-\mathrm{N} 2$ & $175.3(2)$ \\
\hline $\mathrm{N} 1-\mathrm{Cu} 1-\mathrm{N} 2$ & $84.9(2)$ & $\mathrm{O} 1-\mathrm{Cu} 1-\mathrm{O} 2$ & $90.01(18)$ \\
\hline $\mathrm{N} 1-\mathrm{Cu} 1-\mathrm{O} 2$ & 165.81(19) & $\mathrm{N} 2-\mathrm{Cu} 1-\mathrm{O} 2$ & $91.5(2)$ \\
\hline \multicolumn{4}{|c|}{2} \\
\hline $\mathrm{Cu} 1-\mathrm{O} 1$ & $1.895(3)$ & $\mathrm{Cu} 1-\mathrm{N} 1$ & $1.938(4)$ \\
\hline $\mathrm{Cu} 1-\mathrm{N} 2$ & $2.021(4)$ & $\mathrm{Cu} 1-\mathrm{N} 3$ & $1.969(4)$ \\
\hline $\mathrm{Cu} 1-\mathrm{N} 3 \mathrm{~A}$ & $3.184(5)$ & Cu1-N5A & $2.565(5)$ \\
\hline $\mathrm{O} 1-\mathrm{Cu} 1-\mathrm{N} 1$ & $92.84(15)$ & $\mathrm{O} 1-\mathrm{Cu} 1-\mathrm{N} 3$ & $88.92(16)$ \\
\hline $\mathrm{N} 1-\mathrm{Cu} 1-\mathrm{N} 3$ & $176.27(19)$ & $\mathrm{O} 1-\mathrm{Cu} 1-\mathrm{N} 2$ & $170.86(17)$ \\
\hline N1-Cu1-N2 & $84.39(17)$ & N3-Cu1-N2 & $93.37(18)$ \\
\hline $\mathrm{O} 1-\mathrm{Cu} 1-\mathrm{N} 3 \mathrm{~A}$ & $88.01(18)$ & $\mathrm{N} 1-\mathrm{Cu} 1-\mathrm{N} 3 \mathrm{~A}$ & $72.81(18)$ \\
\hline N2-Cu1-N3A & $82.85(18)$ & N3-Cu1-N3A & $103.99(18)$ \\
\hline N5B-Cu1-N3A & $162.34(18)$ & O1-Cu1-N5B & $96.89(18)$ \\
\hline N1-Cu1-N5B & $89.96(18)$ & $\mathrm{N} 2-\mathrm{Cu} 1-\mathrm{N} 5 \mathrm{~B}$ & $91.82(18)$ \\
\hline N3-Cu1-N5B & $93.09(18)$ & & \\
\hline \multicolumn{4}{|c|}{ Symmetry codes: A: $1-x, 2-y, 1-z ; \mathrm{B}: 1-x, 1-y, 1-z$} \\
\hline \multicolumn{4}{|c|}{3} \\
\hline $\mathrm{Cu} 1-\mathrm{O} 1$ & $1.892(4)$ & $\mathrm{Cu} 1-\mathrm{N} 1$ & $1.935(4)$ \\
\hline $\mathrm{Cu} 1-\mathrm{N} 2$ & $2.017(4)$ & $\mathrm{Cu} 1-\mathrm{Br} 2$ & $2.3996(8)$ \\
\hline $\mathrm{O} 1-\mathrm{Cu} 1-\mathrm{N} 1$ & $93.02(16)$ & $\mathrm{O} 1-\mathrm{Cu} 1-\mathrm{N} 2$ & $176.36(18)$ \\
\hline $\mathrm{N} 1-\mathrm{Cu} 1-\mathrm{N} 2$ & $84.57(18)$ & $\mathrm{O} 1-\mathrm{Cu} 1-\mathrm{Br} 2$ & $89.01(11)$ \\
\hline $\mathrm{N} 1-\mathrm{Cu} 1-\mathrm{Br} 2$ & $161.31(13)$ & $\mathrm{N} 2-\mathrm{Cu} 1-\mathrm{Br} 2$ & $94.15(13)$ \\
\hline \multicolumn{4}{|c|}{4} \\
\hline $\mathrm{Cu} 1-\mathrm{O} 1$ & $1.918(3)$ & $\mathrm{Cu} 1-\mathrm{N} 1$ & $1.970(4)$ \\
\hline $\mathrm{Cu} 1-\mathrm{N} 2$ & $2.044(4)$ & $\mathrm{Cu} 1-\mathrm{Cl} 1$ & $2.3001(17)$ \\
\hline $\mathrm{O} 1-\mathrm{Cu} 1-\mathrm{N} 1$ & $93.14(14)$ & $\mathrm{O} 1-\mathrm{Cu} 1-\mathrm{N} 2$ & $174.39(16)$ \\
\hline $\mathrm{N} 1-\mathrm{Cu} 1-\mathrm{N} 2$ & $84.56(16)$ & $\mathrm{O} 1-\mathrm{Cu} 1-\mathrm{Cl} 1$ & $89.63(10)$ \\
\hline $\mathrm{N} 1-\mathrm{Cu} 1-\mathrm{Cl} 1$ & $161.44(12)$ & N2-Cu1-Cl1 & $94.18(12)$ \\
\hline
\end{tabular}




\section{7. Measurement of Urease Inhibitory Activity}

The assay mixture, containing $25 \mu \mathrm{L}$ (10U) of jack bean urease which was replaced by $25 \mu \mathrm{L}$ of cell suspension $\left(4.0 \times 10^{7} \mathrm{CFU} / \mathrm{mL}\right)$ for the urease assay of intact cells and $25 \mu \mathrm{L}$ of the test compound, was pre-incubated for $1.5 \mathrm{~h}$ at room temperature in a 96-well assay plate. Urease activity was determined by measuring ammonia production using the indophenol method as described by Weatherburn. ${ }^{14}$

\section{Results and Discussion}

\section{1. General Chemistry}

The Schiff base ligand was prepared by reaction of 4-bromosalicylaldehyde and $N$-methylethane-1,2-diamine in methanol. The ligand was not isolated and purified, and was used to prepare the complexes with copper salts (Scheme 1). Elemental analyses of the complexes are in accordance with the molecular structures proposed by the X-ray analysis. The complexes are stable in air at room temperature. The molar conductivity of complexes measured in methanol at concentration of $10^{-3} \mathrm{~mol} \mathrm{~L}^{-1}$ is $20-45$ $\Omega^{-1} \mathrm{~cm}^{2} \mathrm{~mol}^{-1}$, indicating the non-electrolytic nature of them in solution. ${ }^{15}$

\section{2. IR and UV-Vis Spectra}

In the IR spectra the weak and sharp absorptions in the range $3150-3200 \mathrm{~cm}^{-1}$ are assigned to the $\mathrm{N}-\mathrm{H}$ vibrations of the Schiff base ligands. The characteristic $\mathrm{C}=\mathrm{N}$ stretching is observed at $1630 \mathrm{~cm}^{-1}$ as intense signals. ${ }^{16}$ The Schiff base ligand coordination to the copper atoms is substantiated by weak bands in the low wavenumbers $400-600 \mathrm{~cm}^{-1}$ corresponding to $v(\mathrm{Cu}-\mathrm{N})$ and $v(\mathrm{Cu}-\mathrm{O})$. The IR spectrum of complex 2 shows the most intense absorption band at $2078 \mathrm{~cm}^{-1}$ corresponding to the azide ligand. ${ }^{17}$ The Ar-O stretching bands are located at 1150 $1200 \mathrm{~cm}^{-1}$. $^{18}$ The spectrum of complex 1 displays three absorption bands at 1421,1272 and $1086 \mathrm{~cm}^{-1}$ corresponding to the nitrate ligand. ${ }^{19}$

In the UV-vis spectra the bands at 230, 245-250 nm and $270-280 \mathrm{~nm}$ are attributed to the $\pi-\pi^{*}$ and $n-\pi^{*}$ transitions. ${ }^{20}$ The bands at $360-370 \mathrm{~nm}$ can be assigned to the ligand to metal charge transfer transition (LMCT).$^{21}$

\section{3. Structure Description of Complex 1}

The molecular structure of complex $\mathbf{1}$ is shown in Fig. 1. The $[\mathrm{CuL}]$ units are linked by acetate ligand, to form one dimensional chain structure. The $\mathrm{Cu}$ atom is in a square pyramidal geometry, with the basal plane defined by the phenolate $\mathrm{O}$, imino $\mathrm{N}$ and amino $\mathrm{N}$ atoms of the Schiff base ligand, and one acetate $\mathrm{O}$ atom, and with the apical position occupied by one acetate $\mathrm{O}$ atom. The $\mathrm{Cu}$ atom deviates from the plane defined by the four basal donor atoms by $0.078(2) \AA$. The square pyramidal coordination is distorted from ideal model, as evidenced by the bond angles in the basal plane, with cis and trans angles in the ranges of $84.9(2)-94.7(2)^{\circ}$ and $165.8(2)-175.3(2)^{\circ}$, respectively. The $\mathrm{Cu}-\mathrm{O}$ and $\mathrm{Cu}-\mathrm{N}$ bond lengths are comparable to those observed in Schiff base copper complexes with acetate ligands. ${ }^{22}$

In the crystal structure of the complex, the molecules are linked through $\mathrm{N}-\mathrm{H}$... $\mathrm{O}$ and $\mathrm{C}-\mathrm{H}$... O hydrogen bonds (Table 3), to form one dimensional chain along the $b$ axis (Fig. 2).

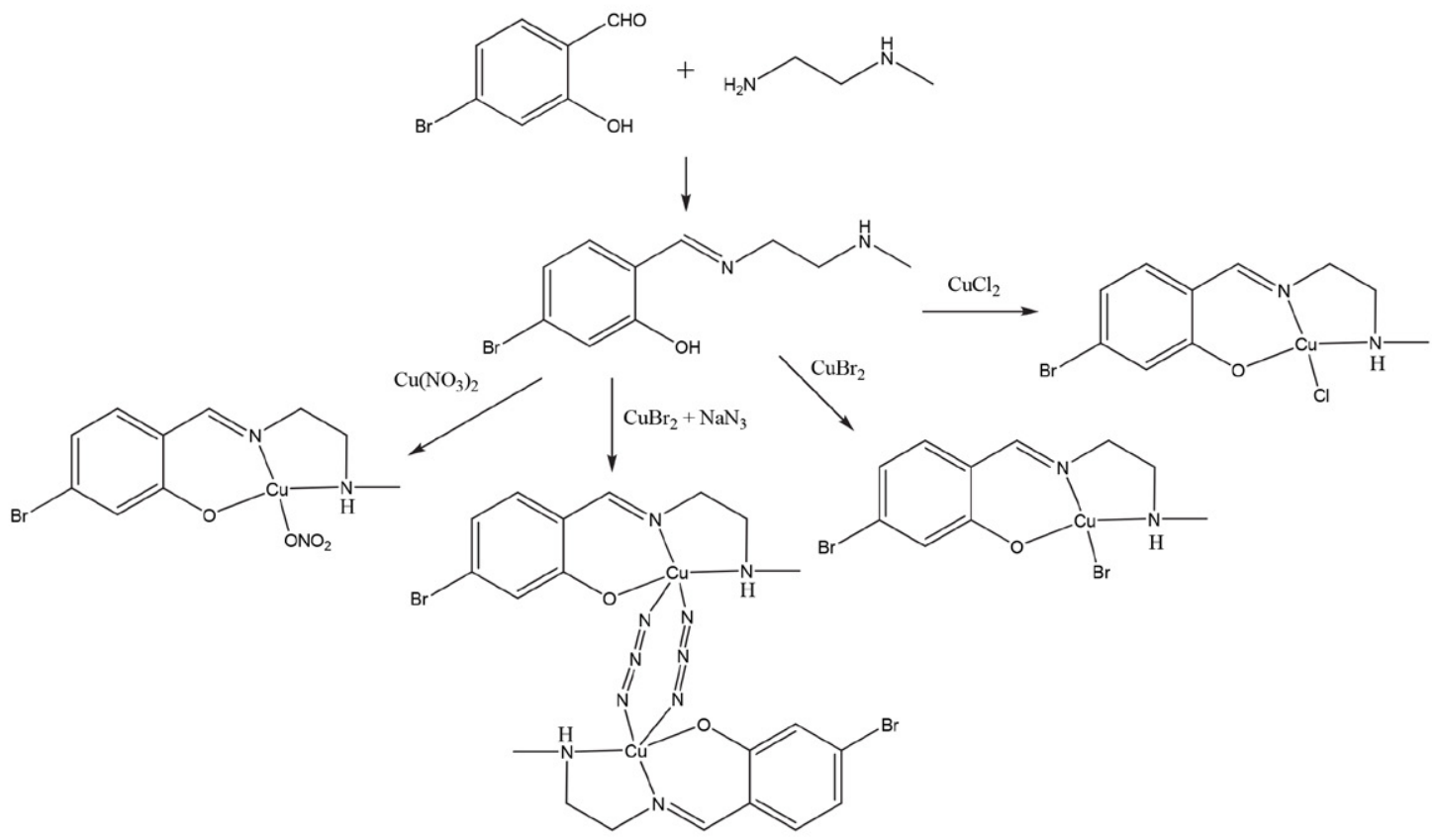

Scheme 1. The synthetic procedure for the Schiff base and the complexes. 


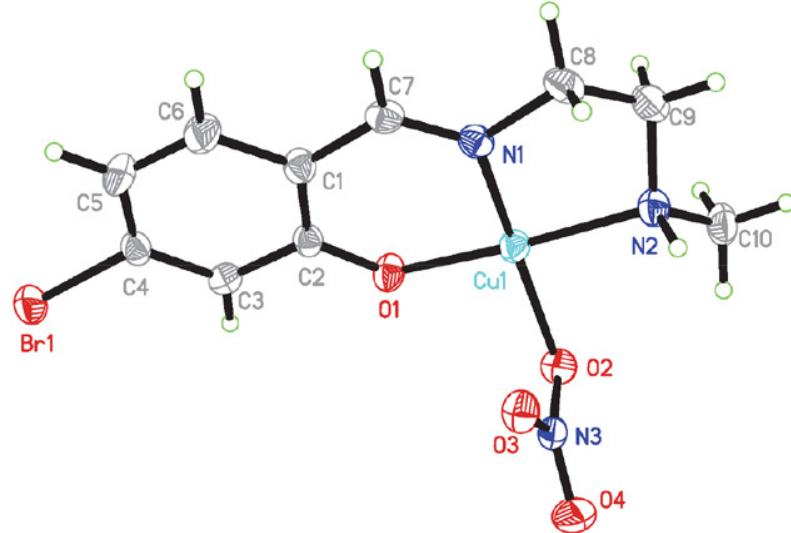

Fig. 1. A perspective view of the molecular structure of complex $\mathbf{1}$. Thermal ellipsoids are drawn at the $30 \%$ probability level.

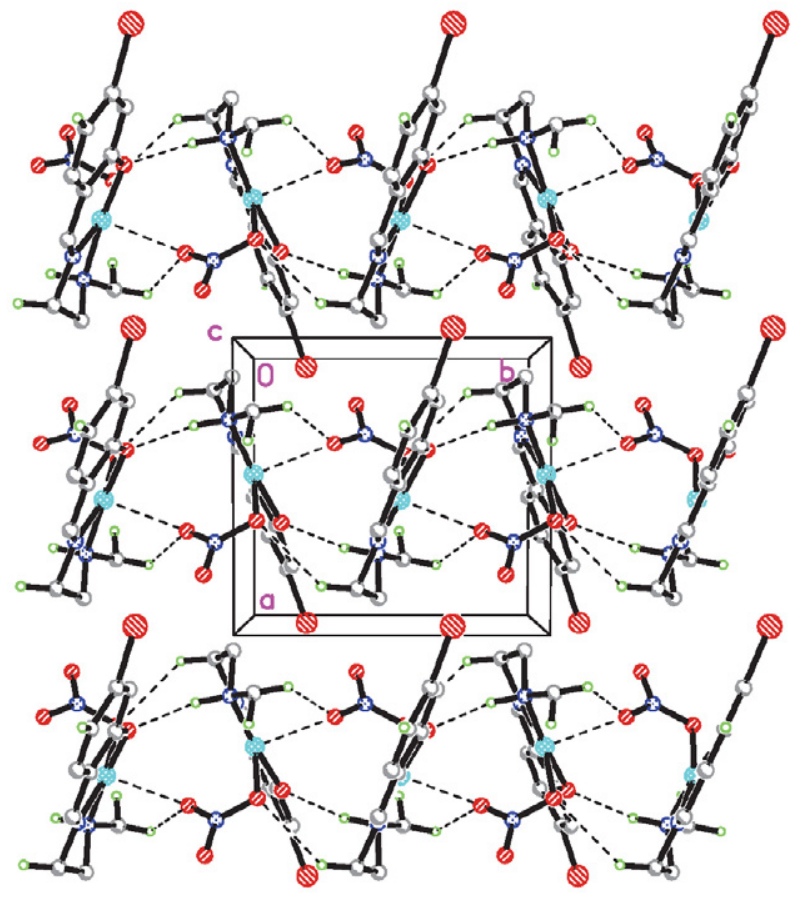

Fig. 2. Molecular packing structure of complex 1. Hydrogen bonds are drawn as dashed lines.

\section{4. Structure Description of Complex 2}

The molecular structure of the $\mu_{1,1,3}$-azido bridged polynuclear complex $\mathbf{2}$ is shown in Fig. 3. The adjacent two $\mathrm{Cu}$ atoms are bridged by two azide ligands, with distances of 3.314(1) and 5.000(1) $\AA$, respectively. The $\mathrm{Cu}$ atom is coordinated in octahedral geometry, with the equatorial plane defined by the phenolate $\mathrm{O}$, imino $\mathrm{N}$ and amino $\mathrm{N}$ atoms of the Schiff base ligand, and one azide $\mathrm{N}$ atom, and with the axial positions occupied by two azide $\mathrm{N}$ atoms. The $\mathrm{Cu}$ atom deviates from the equatorial plane by $0.102(2) \AA$. The octahedral coordination is distorted from ideal model, as evidenced by the bond angles. The cis and trans angles in the equatorial plane are in the ranges of
84.4(2)-93.4(2) ${ }^{\circ}$ and $170.9(2)-176.3(2)^{\circ}$, respectively. The bond angles among the axial and equatorial donor atoms are in the range of $81.8(2)-96.9(2)^{\circ}$. The $\mathrm{Cu}-\mathrm{O}$ and $\mathrm{Cu}-\mathrm{N}$ bond lengths are comparable to those observed in Schiff base copper complexes with azide ligands. ${ }^{23}$

In the crystal structure of the complex, the molecules are linked by azide ligands, to form one dimensional chain along the $b$ axis. There are $\mathrm{N}-\mathrm{H} \cdots \mathrm{O}$ and $\mathrm{C}-\mathrm{H} \cdots \mathrm{N}$ hydrogen bonds (Table 3 ) within the chains (Fig. 4).

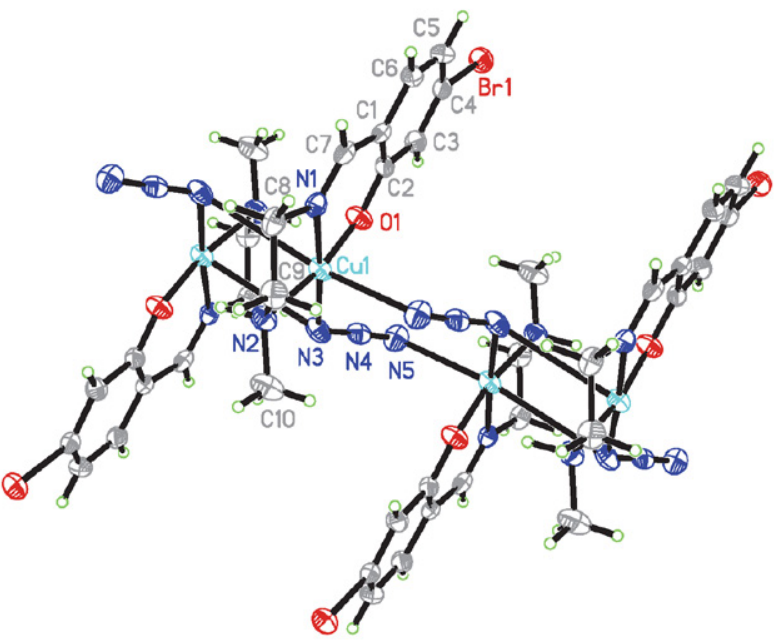

Fig. 3. A perspective view of the molecular structure of complex 2 . Thermal ellipsoids are drawn at the $30 \%$ probability level. Unlabeled atoms are related to the symmetry operations $1-x, 2-y, 1-z$ and B: $1-x, 1-y, 1-z$.

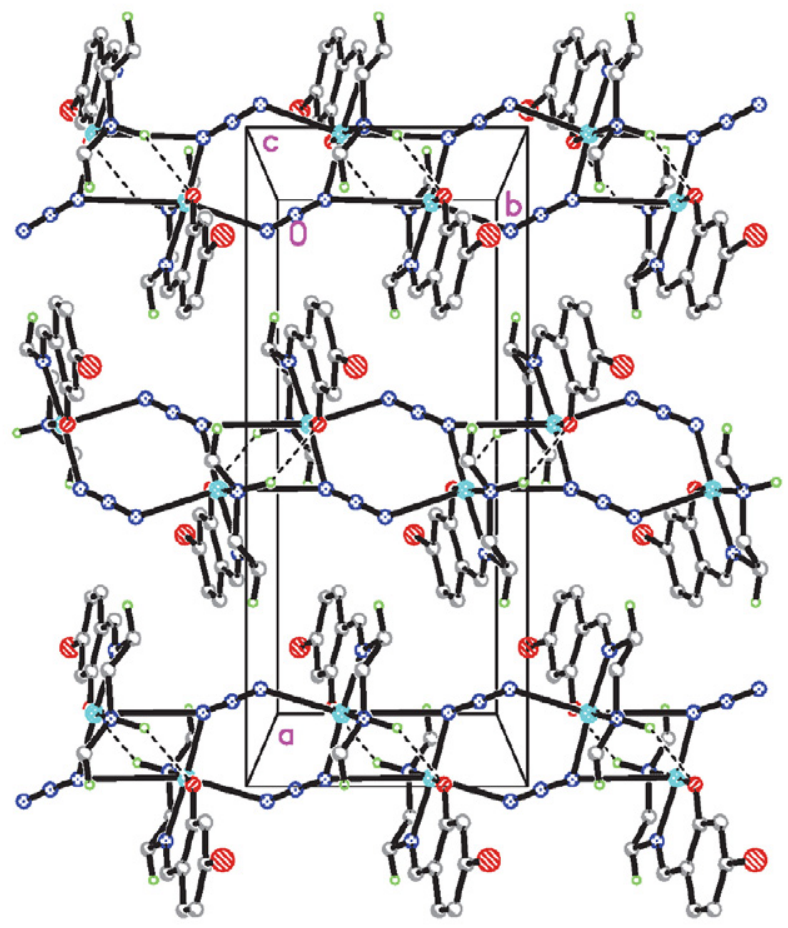

Fig. 4. Molecular packing structure of complex 2. Hydrogen bonds are drawn as dashed lines. 


\section{5. Structure Description of Complexes 3 and 4}

Molecular structures of complexes 3 and 4 are shown in Figs. 5 and 6, respectively. The two complexes are isostructural mononuclear copper compounds. The $\mathrm{Cu}$ atom in each complex is coordinated by the phenolate $\mathrm{O}$, imino $\mathrm{N}$ and amino $\mathrm{N}$ atoms of the Schiff base ligand, and one halide atom, viz. Br for 3 and $\mathrm{Cl}$ for 4 . The $\mathrm{Cu}$ atoms deviate from the planes defined by the four donor atoms by $0.153(2) \AA$ for 3 and $0.129(2) \AA$ for 4. The square planar coordination is distorted from ideal model, as evidenced by the bond angles, with cis and trans angles in the ranges of $84.6(2)-94.2(1)^{\circ}$ and $161.3(1)-176.4(2)^{\circ}$ for 3 , and $84.6(2)-94.2(1)^{\circ}$ and $161.4(1)-174.4(2)^{\circ}$ for 4 , respectively. The $\mathrm{Cu})-\mathrm{O}$ and $\mathrm{Cu})-\mathrm{N}$ bond lengths are comparable to those observed in Schiff base copper complexes with halide ligands. ${ }^{24}$

In the crystal structure of complex 3 , the molecules are linked through $\mathrm{N}-\mathrm{H} \cdots \mathrm{O}$ and $\mathrm{C}-\mathrm{H} \cdots \mathrm{Br}$ hydrogen bonds (Table 3), to form zigzag chains along the $b$ axis (Fig. 7). In the crystal structure of complex $\mathbf{4}$, the molecules are linked through $\mathrm{N}-\mathrm{H}$... O hydrogen bonds (Table 3 ), to form zigzag chains along the $b$ axis (Fig. 8).

Table 3. Hydrogen bond distances $(\AA)$ and bond angles $\left(^{\circ}\right)$ for the complexes.

\begin{tabular}{lllll}
\hline $\begin{array}{l}\boldsymbol{D}-\mathrm{H} \cdots \boldsymbol{A} \\
(\boldsymbol{D}-\mathrm{H} \cdots \boldsymbol{A})\end{array}$ & $\boldsymbol{d}(\boldsymbol{D}-\mathbf{H})$ & $\boldsymbol{d}(\mathbf{H} \cdots \boldsymbol{A})$ & $\boldsymbol{d}(\boldsymbol{D} \cdots \boldsymbol{A})$ & Angle \\
\hline $\mathrm{N} 2-\mathrm{H} 2 \cdots \mathrm{O}^{\# 1}$ & 0.98 & 2.08 & $3.037(6)$ & $166(5)$ \\
$\mathrm{C} 5-\mathrm{H} 5 \cdots 4^{\# 2}$ & 0.93 & 2.59 & $3.448(6)$ & $153(5)$ \\
$\mathrm{C} 8-\mathrm{H} 8 \mathrm{~A} \cdots \mathrm{O} 2^{\# 1}$ & 0.97 & 2.55 & $3.340(6)$ & $139(5)$ \\
$\mathrm{C} 10-\mathrm{H} 10 \mathrm{C} \cdots \mathrm{O} 33^{\# 3}$ & 0.96 & 2.51 & $3.145(6)$ & $124(5)$ \\
\hline & & $\mathbf{2}$ & & \\
$\mathrm{N} 2-\mathrm{H} 2 \cdots \mathrm{O} 1^{\# 4}$ & 0.98 & 2.24 & $3.067(5)$ & $142(5)$ \\
$\mathrm{C} 8-\mathrm{H} 8 \mathrm{~B} \cdots \mathrm{N}^{\# 5}$ & 0.97 & 2.62 & $3.510(5)$ & $152(5)$ \\
\hline & & $\mathbf{3}$ & & \\
$\mathrm{N} 2-\mathrm{H} 2 \mathrm{~B} \cdots \mathrm{O} 1^{\# 6}$ & 0.98 & 2.48 & $3.311(6)$ & $143(6)$ \\
$\mathrm{N} 2-\mathrm{H} 2 \cdots \mathrm{Br}^{\# 6}$ & 0.98 & 3.04 & $3.797(5)$ & $135(6)$ \\
$\mathrm{C} 7-\mathrm{H} 7 \cdots \mathrm{Br}^{\# 7}$ & 0.93 & 2.88 & $3.779(5)$ & $163(6)$ \\
\hline & & $\mathbf{4}$ & & \\
$\mathrm{N} 2-\mathrm{H} 2 \cdots \mathrm{O} 1^{\# 8}$ & 0.98 & 2.39 & $3.240(6)$ & $145(6)$ \\
\hline
\end{tabular}

Symmetry codes: \#1: $1-x,-1-y, 1-z ; \# 2: x, y, 1+z ; \# 3: 1-x,-1 / 2$ $+y, 1-z ; \# 4:-x, 1-y,-z ; \# 5: 1 / 2-x, 1 / 2+y, z ; \# 6:-x, 1 / 2+y, 1 / 2-z$ \#7: $1 / 2+x, y, 1 / 2-z ; \# 8:-x,-1 / 2+y, 1 / 2-z$.

\section{6. Urease Inhibitory Activity}

We investigated the urease inhibition of the complexes in an effort to find more potent compounds in comparison with previously reported compounds. The $\mathrm{IC}_{50}$ values of complexes $\mathbf{1}, \mathbf{3}$ and $\mathbf{4}$ are $1.72 \pm 0.33,1.05$ \pm 0.26 and $0.77 \pm 0.15 \mu \mathrm{mol} \mathrm{L}{ }^{-1}$, respectively. However,

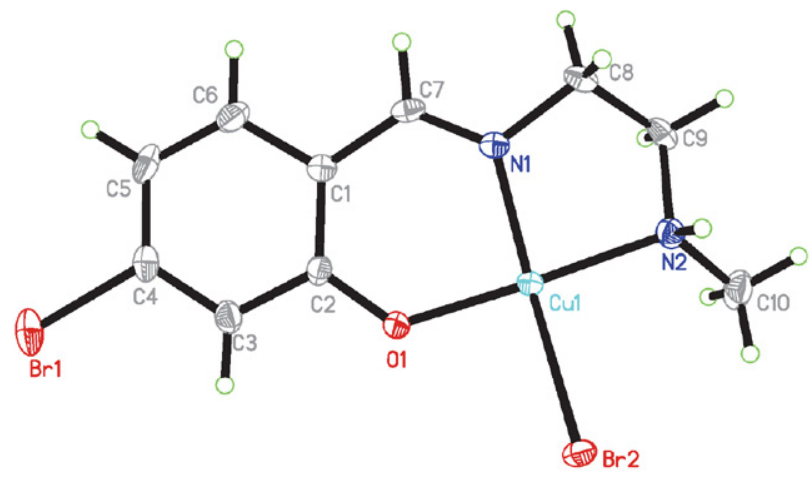

Fig. 5. A perspective view of the molecular structure of complex 3. Thermal ellipsoids are drawn at the $30 \%$ probability level.

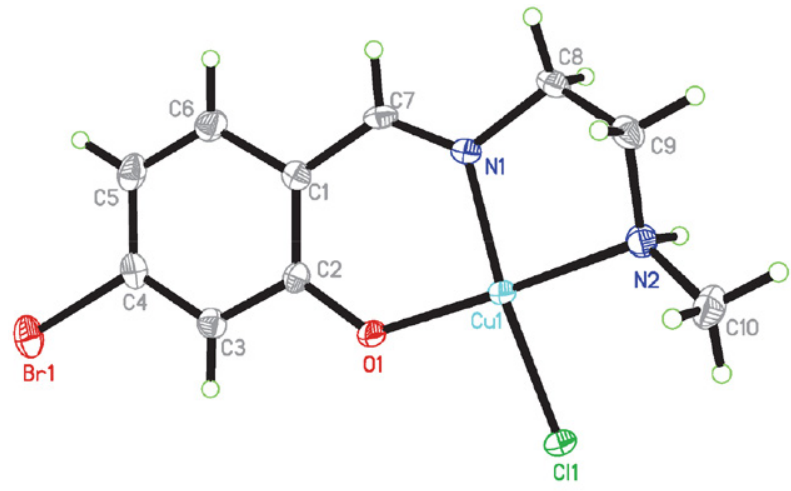

Fig. 6. A perspective view of the molecular structure of complex 4 . Thermal ellipsoids are drawn at the $30 \%$ probability level.

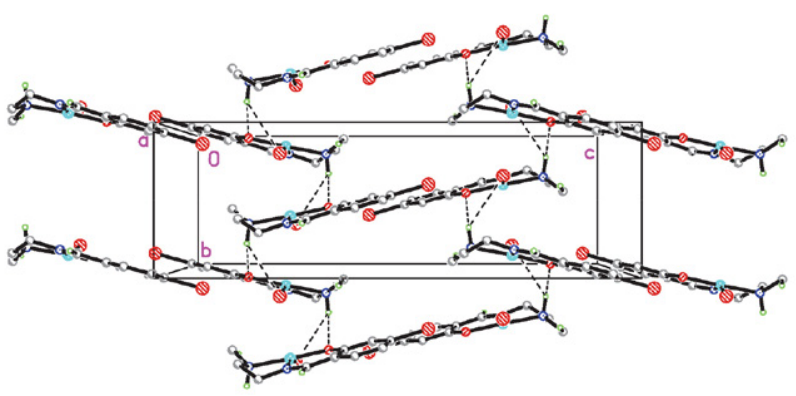

Fig. 7. Molecular packing structure of complex 3. Hydrogen bonds are drawn as dashed lines.

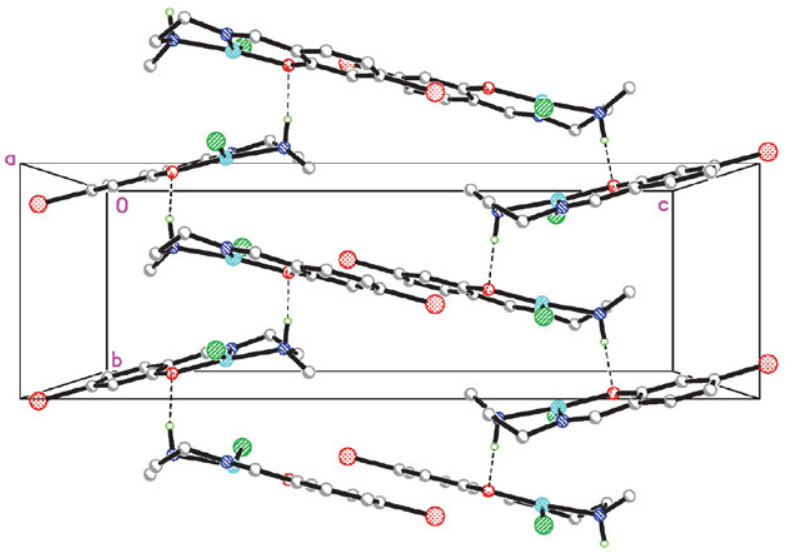

Fig. 8. Molecular packing structure of complex 4. Hydrogen bonds are drawn as dashed lines. 
complex 2 has medium activity, with $\mathrm{IC}_{50}$ value of $8.31 \pm$ $1.29 \mu \mathrm{mol} \mathrm{L}{ }^{-1}$. The copper complexes have from medium to strong urease inhibitory activity, which is in accordance with those reported in literature. ${ }^{25}$ Complex 2 has weaker activity than the other complexes, which might due to the larger size arise from polymerization. The hydrophobic area of the enzyme cannot comfortably accommodate the molecules with large sizes. Acetohydroxamic acid (AHA) was used as a reference, and with $\mathrm{IC}_{50}$ value of $27.8 \pm 2.12$ $\mu \mathrm{mol} \mathrm{L}{ }^{-1}$. Thus, the copper complexes would be potential urease inhibitors that deserve further study.

\section{Conclusion}

In summary, four new copper complexes with the Schiff base ligand 5-bromo-2-(((2-methylamino)ethyl) imino)methyl)phenolate have been synthesized and characterized. X-ray single crystal structure analysis indicates that the $\mathrm{Cu}$ atoms in complexes 1, 3 and $\mathbf{4}$ are in square planar geometry, and those in complex $\mathbf{2}$ are in octahedral geometry. The copper complexes have strong urease inhibitory activity, which deserves further study to explore new and efficient urease inhibitors.

\section{Supplementary Materials}

$\mathrm{X}$-ray crystallographic data for the complexes have been deposited with the Cambridge Crystallographic Data Centre (The Director, CCDC, 12 Union Road, Cambridge, CB2 1 EZ, UK; e-mail: deposit@ccdc.cam.ac.uk; http:// www.ccdc.cam.ac.uk; fax: +44-(0)1223-336033) and are available free of charge on request, quoting the deposition numbers CCDC 2083691-2083694.

\section{Acknowledgments}

This project was supported by the Heilongjiang Province Qiqihar Ecological Environment Monitoring Center.

\section{References}

1. L. Casali, L. Mazzei, O. Shemchuk, L. Sharma, K. Honer, F. Grepioni, S. Ciurli, D. Braga, J. Baltrusaitis, ACS Sustainable Chem. Eng. 2019, 7, 2852-2859.

DOI:10.1021/acssuschemeng.8b06293

2. P. A. Karplus, M. A. Pearson, R. P. Hausinger, Acc. Chem. Res. 1997, 30, 330-337. DOI:10.1021/ar960022j

3. (a) B. Bano, Kanwal, K. M. Khan, A. Lodhi, U. Salar, F. Begum, M. Ali, M. Taha, S. Perveen, Bioorg. Chem. 2018, 80, 129-144; DOI:10.1016/j.bioorg.2018.06.007

(b) P. Y. Oikawa, C. Ge, J. Wang, J.R. Eberwein, L. L. Liang, L. A. Allsman, D. A. Grantz, G. D. Jenerette, Nat. Commun. 2015, 6, 8753; DOI:10.1038/ncomms9753 (c) D. Coskun, D. T. Britto, W. Shi, H. J. Kronzucker, Nat. Plants 2017, 3, 17074. DOI:10.1038/nplants.2017.74

4. (a) S. V. Krupa, Environ. Pollut. 2003, 124, 179-221; DOI:10.1016/S0269-7491(02)00434-7 (b) J. L. Hand, B. A. Schichtel, M. Pitchford, W. C. Malm, N. H. Frank, J. Geophys. Res. Atmos. 2012, 117, D05209.

5. J. N. Galloway, F. J. Dentener, D. G. Capone, E. W. Boyer, R. W. Howarth, S. P. Seitzinger, G. P. Asner, C. C. Cleveland, P. A. Green, E. A. Holland, D. M. Karl, A. F. Michaels, J. H. Porter, A. R. Townsend, C. J. Vorosmarty, Biogeochemistry 2004, 70, 153-226. DOI:10.1007/s10533-004-0370-0

6. (a) A. Saeed, M. S. Khan, H. Rafique, M. Shahid, J. Iqbal. Bioorg. Chem. 2014, 52, 1-7; DOI:10.1016/j.bioorg.2013.10.001 (b) A. Hameed, K. M. Khan, S. T. Zehra, R. Ahmed, Z. Shafiq, S. M. Bakht, M. Yaqub, M. Hussain, A. de la Vega de Leon, N. Furtmann, J. Bajorath, H. A. Shad, M. N. Tahir, J. Iqbal, Bioorg. Chem. 2015, 61, 51-57.

DOI:10.1016/j.bioorg.2015.06.004

7. F. Iftikhar, Y. Ali, F. A. Kiani, S. F. Hassan, T. Fatima, A. Khan, B. Niaz, A. Hassan, F. L. Ansari, U. Rashid, Bioorg. Chem. 2017, 74, 53-65. DOI:10.1016/j.bioorg.2017.07.003

8. (a) M. J. Todd, R. P. Hausinger, Biochemistry 2000, 39, 53895396; DOI:10.1021/bi992287m

(b) K. M. Khan, F. Rahim, A. Khan, M. Shabeer, S. Hussain, W. Rehman, M. Taha, M. Khan, S. Perveen, M. I. Choudhary, Bioorg. Med. Chem. 2014, 22, 4119-4123;

DOI:10.1016/j.bmc.2014.05.057

(c) W.-W. Ni, H.-L. Fang, Y.-X. Ye, W.-Y. Li, C.-P. Yuan, D.-D. Li, S.-J. Mao, S.-E. Li, Q.-H. Zhu, H. Ouyang, Z.-P. Xiao, H.-L. Zhu, Future Med. Chem. 2020, 12, 1633-1645;

DOI:10.4155/fmc-2020-0048

(d) Q. Liu, W.-K. Shi, S.-Z. Ren, W.-W. Ni, W.-Y. Li, H.-M. Chen, P. Liu, J. Yuan, X.-S. He, J.-J. Liu, P. Cao, P.-Z. Yang, Z.P. Xiao, H.-L. Zhu, Eur. J. Med. Chem. 2018, 156, 126-136; DOI:10.1016/j.ejmech.2018.06.065

(e) W.-W. Ni, Q. Liu, S.-Z. Ren, W.-Y. Li, L.-L. Yi, H. Jing, L.X. Sheng, Q. Wan, P.-F. Zhong, H.-L. Fang, H. Ouyang, Z.-P. Xiao, H.-L. Zhu, Bioorg. Med. Chem. 2018, 26, 4145-4152; DOI:10.1016/j.bmc.2018.07.003

(f) W.-K. Shi, R.-C. Deng, P.-F. Wang, Q.-Q. Yue, Q. Liu, K.-L. Ding, M.-H. Yang, H.-Y. Zhang, S.-H. Gong, M. Deng, W.-R. Liu, Q.-J. Feng, S. Tang, Z.-P. Xiao, H.-L. Zhu, Bioorg. Med. Chem. 2016, 24, 4519-4527;

DOI:10.1016/j.bmc.2016.07.052

(g) Z.-P. Xiao, W.-K. Shi, P.-F. Wang, W. Wei, X.-T. Zeng, J.-R. Zhang, N. Zhu, M. Peng, B. Peng, X.-Y. Lin, H. Ouyang, X.-C. Peng, G.-C. Wang, H.-L. Zhu, Bioorg. Med. Chem. 2015, 23, 4508-4513; DOI:10.1016/j.bmc.2015.06.014

(h) Z.-P. Xiao, Z.-Y. Peng, J.-J. Dong, R.-C. Deng, X.-D. Wang, H. Ouyang, P. Yang, J. He, Y.-F. Wang, M. Zhu, X.-C. Peng, W.-X. Peng, H.-L. Zhu, Eur. J. Med. Chem. 2013, 68, 212-221; DOI:10.1016/j.ejmech.2013.07.047

(i) Z.-P. Xiao, Z.-Y. Peng, J.-J. Dong, J. He, H. Ouyang, Y.-T. Peng, C.-L. Lu, W.-Q. Lin, J.-X. Wang, Y.-P. Xiang, H.-L. Zhu, Eur. J. Med. Chem. 2013, 63, 685-695.

DOI:10.1016/j.ejmech.2013.03.016 
9. (a) M. K. Rauf, S. Yaseen, A. Badshah, S. Zaib, R. Arshad, Imtiaz-ud-Din, M. N. Tahir, J. Iqbal, J. Biol. Inorg. Chem. 2015, 20, 541-554; DOI:10.1007/s00775-015-1239-5

(b) X. Dong, Y. Li, Z. Li, Y. Cui, H. Zhu, J. Inorg. Biochem. 2012, 108, 22-29; DOI:10.1016/j.jinorgbio.2011.12.006 (c) Y. Gou, M. Yu, Y. Li, Y. Peng, W. Chen, Inorg. Chim. Acta 2013, 404, 224-229. DOI:10.1016/j.ica.2013.03.045

10. (a) H. Kargar, Transit. Met. Chem. 2014, 39, 811-817; DOI:10.1007/s11243-014-9863-4

(b) A. Sahraei, H. Kargar, M. Hakimi, M. N. Tahir, J. Mol. Struct. 2017, 1149, 576-584;

DOI:10.1016/j.molstruc.2017.08.022

(c) A. Sahraei, H. Kargar, M. Hakimi, M. N. Tahir, Transit. Met. Chem. 2017, 42, 483-489;

DOI:10.1007/s11243-017-0152-x

(d) A. Jamshidvand, M. Sahihi, V. Mirkhani, M. Moghadam, I. Mohammadpoor-Baltork, S. Tangestaninejad, H.A. Rudbari, H. Kargar, R. Keshavarzi, S. Gharaghani, J. Mol. Liquids 2018, 253, 61-71; DOI:10.1016/j.molliq.2018.01.029

(e) H. Kargar, R. Behjatmanesh-Ardakani, V. Torabi, M. Kashani, Z. Chavoshpour-Natanzi, Z. Kazemi, V. Mirkhani, A. Sahraei, M. N. Tahir, M. Ashfaq, K. S. Munawar, Polyhedron 2021, 195, 114988; DOI:10.1016/j.poly.2020.114988

(f) H. Kargar, F. Aghaei-Meybodi, R. Behjatmanesh-Ardakani, M. R. Elahifard, V. Torabi, M. Fallah-Mehrjardi, M. N. Tahir, M. Ashfaq, K. S. Munawar, J. Mol. Struct. 2021, 1230, 129908; DOI:10.1016/j.molstruc.2021.129908

(g) H. Kargar, A. A. Ardakani, M. N. Tahir, M. Ashfaq, K. S. Munawar, J. Mol. Struct. 2021, 1233, 130112.

DOI:10.1016/j.molstruc.2021.130112

11. (a) H. Zhu, Z.-Z. Wang, B. Qi, T. Huang, H.-L. Zhu, J. Coord. Chem. 2013, 66, 2980-2991;

DOI:10.1080/00958972.2013.821198

(b) L. Habala, A. Roller, M. Matuska, J. Valentova, A. Rompel, F. Devinsky, Inorg. Chim. Acta 2014, 421, 423-426;

DOI:10.1016/j.ica.2014.06.035

(c) F.-M. Wang, L.-J. Li, G.-W. Zang, T.-T. Deng, Z.-L. You, Acta Chim. Slov. 2020, 67, 1155-1162;

DOI:10.17344/acsi.2020.6056

(d) H. Zhao, X.-P. Tan, Q.-A. Peng, C.-Z. Shi, Y.-F. Zhao, Y. Cui, Acta Chim. Slov. 2020, 67, 638-643.

DOI:10.17344/acsi.2019.5644

12. G. M. Sheldrick. SAINT (version 6.02), SADABS (version 2.03), Madison (WI, USA): Bruker AXS Inc, 2002.

13. (a) G. M. Sheldrick, Acta Crystallogr. 2015, C71, 3-8; (b) G. M. Sheldrick. SADABS Program for Empirical Absorption Correction of Area Detector, University of Gottingen, Germany 1996.

14. M. W. Weatherburn, Anal. Chem. 1967, 39, 971-974.

DOI:10.1021/ac60252a045

15. W. J. Geary, Coord. Chem. Rev. 1971, 7, 81-122.

DOI:10.1016/S0010-8545(00)80009-0

16. K. R. Surati, B. T. Thaker, Spectrochim. Acta A 2010, 75, 235242. DOI:10.1016/j.saa.2009.10.018

17. (a) S. S. Massoud, F. A. Mautner. Inorg. Chim. Acta, 2005, 358, 3334-3340; DOI:10.1016/j.ica.2005.05.007 (b) A. Ray, S. Banerjee, R. J. Butcher, C. Desplanches, S. Mitra, Polyhedron 2008, 27, 2409-2415.

DOI:10.1016/j.poly.2008.04.018

18. Y.-M. Zhou, X.-R. Ye, F.-B. Xin, X.-Q. Xin, Transit. Met. Chem. 1999, 24, 118-120. DOI:10.1023/A:1006989707001

19. M. F. Iskander, T. E. Khalil, R. Werner, W. Haase, I. Svoboda, H. Fuess, Polyhedron 2000, 19, 949-958.

DOI:10.1016/S0277-5387(00)00340-5

20. L. Pogany, J. Moncol, M. Gal, I. Salitros, R. Boca, Inorg. Chim. Acta 2017, 462, 23-29. DOI:10.1016/j.ica.2017.03.001

21. A. Jayamani, M. Sethupathi, S. O. Ojwach, N. Sengottuvelan, Inorg. Chem. Commun. 2017, 84, 144-149.

DOI:10.1016/j.inoche.2017.08.013

22. (a) P. Bhowmik, S. Chattopadhyay, A. Ghosh, Inorg. Chim. Acta 2013, 396, 66-71; DOI:10.1016/j.ica.2012.10.003

(b) K. Abe, K. Matsufuji, M. Ohba, H. Okawa, Inorg. Chem. 2002, 41, 4461-4467. DOI:10.1021/ic020002f

23. (a) P. K. Bhaumik, K. Harms, S. Chattopadhyay, Polyhedron 2014, 68, 346-356; DOI:10.1016/j.poly.2013.10.031

(b) J. Wang, Y. Luo, Y. Zhang, Y. Chen, F. Gao, Y. Ma, D. Xian, Z. You, J. Coord. Chem. 2021, 74, 1028-1038.

DOI:10.1080/00958972.2020.1861603

24. (a) H. Adams, D. E. Fenton, S. R. Haque, S. L. Heath, M. Ohba, H. Okawa, S. E. Spey, J. Chem. Soc. Dalton Trans., 2000, 1849-1856; DOI:10.1039/b001395l

(b) M. Das, S. Chattopadhyay, J. Mol. Struct. 2013, 1051, 250258. DOI:10.1016/j.molstruc.2013.07.045

25. (a) L. Pan, C. Wang, K. Yan, K. Zhao, G. Sheng, H. Zhu, X. Zhao, D. Qu, F. Niu, Z. You, J. Inorg. Biochem. 2016, 159, $22-$ 28; DOI:10.1016/j.jinorgbio.2016.02.017

(b) Y. Luo, J. Wang, B. Zhang, Y. Guan, T. Yang, X. Li, L. Xu, J. Wang, Z. You, J. Coord. Chem. 2020, 73, 1765-1777.

DOI:10.1080/00958972.2020.1795645 


\section{Povzetek}

Inhibitorji urease lahko inhibirajo proces razgradnje sečnine in zmanjšajo onesnaženje zraka zaradi sproščanja amonijaka. Sintetizirali smo štiri nove bakrove(II) komplekse $\left[\mathrm{CuL}\left(\mathrm{ONO}_{2}\right)\right]_{\mathrm{n}}(\mathbf{1}),\left[\mathrm{Cu}_{2} \mathrm{~L}_{2}\left(\mu_{1,3}-\mathrm{N}_{3}\right)_{2}\right](\mathbf{2})$, [CuBrL] (3) in $[\mathrm{Cu}-$ $\mathrm{ClL}]$ (4), kjer je $\mathrm{L}=5$-bromo-2-(((2-metilamino)etil)imino)metil)fenolat. Komplekse smo okarakterizirali $\mathrm{z}$ elementno analizo, IR in UV-Vis spektroskopijo, molsko prevodnostjo in monokristalno rentgensko difrakcijo. Rentgenska analiza razkriva, da imajo $\mathrm{Cu}$ atomi v kompleksih 1 in 2 kvadratno piramidalno koordinacijo in v kompleksih 3 in 4 kvadratno planarno koordinacijo. Molekule so povezane $\mathrm{z}$ vodikovimi vezmi in $\pi \cdots \pi$ interakcijami. $\mathrm{S}$ testiranji smo ugotovili, da imajo kompleksi inhibitoren vpliv na ureazo stročnice Canavalia ensiformis.

Except when otherwise noted, articles in this journal are published under the terms and conditions of the Creative Commons Attribution 4.0 International License 